\title{
Quản lý tài sản cá nhân: Vấn đề không "nhỏ"!
}

\author{
DĐDN Data
}

Diễn Đàn Doanh Nghiệp

December 02, 2008

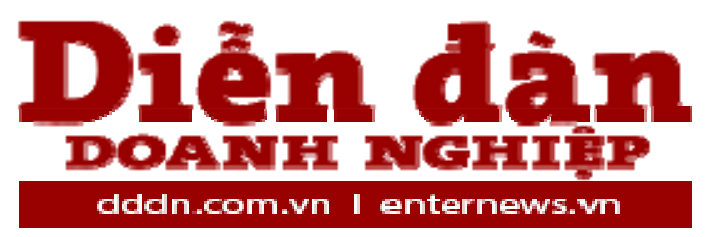

https://enternews.vn/quan-ly-tai-san-ca-nhan-van-de-khong-nho-76255.html 


\section{Diếnờn \\ DOANH NGIIIDP

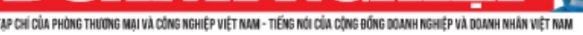

\section{Quản lý tài sản cá nhân: Vấn đề không l"nhỏl"!}

\section{Trong lịch sử loài người, làm giàu luôn là một ước mơ. Tất nhiên mỗi chỗ mỗi lúc, độ nhấn của l"tư cách làm giàul" có khác nhau, nhưng giá trị tài sản vẫn thế. Dẫu gì thì ngay vào lúc này, và tại mảnh đất Việt Nam, ước mơ làm giàu đang ngày càng cháy bỏng trong các tâm hồn từ người chơi Game Online tới các doanh gia ngập mình trong mề-đay chiến tích hào hùng...}

Lời tòa soạn: Làm giàu là một trong những khát vọng chính đáng của con người. Rất, rất nhiều doanh nhân, người nổi tiếng trong các lĩnh vực ngoài kinh doanh đã thành công bắt đầu từ khát vọng đó. Nhưng, không phải ai trong số họ cũng thành công trong việc quản lý tài sản cá nhân. Chúng tôi xin giới thiệu cùng độc giả bài viết của TS Vương Quân Hoàng - Đồng sáng lập hệ thống phân tích và truyền thông kinh doanh www.saga.vn, tác giả của một số tác phẩm nổi tiếng như "Văn minh làm giàu \& nguồn gốc của cải", "Nguyên tắc tài chính toán trong thị trường chứng khoán"... về vấn đề này.

Trong lịch sử loài người, làm giàu luôn là một ước mơ. Tất nhiên mỗi chỗ mỗi lúc, độ nhấn của "tư cách làm giàu" có khác nhau, nhưng giá trị tài sản vẫn thế. Dẫu gì thì ngay vào lúc này, và tại mảnh đất Việt Nam, ước mơ làm giàu đang ngày càng cháy bỏng trong các tâm hồn từ người chơi Game Online tới các doanh gia ngập mình trong mề-đay chiến tích hào hùng...

Nhưng lịch sử cũng đặt ra vấn đề quản lý tài sản cá nhân. Vô số gương tối sáng khác nhau về chuyện quản lý tài sản.

Những năm 80 của thế kỷ trước , nhiều người mê nhạc Michael Jackson. Những ca khúc như Thriller, Liberian Girl, Bad, Smooth Criminal, Beat It, Billie Jean, v.v.. đã mang lại cho người từng được mệnh danh King of Pop này hàng trăm triệu đô-la qua các hợp đồng sáng chói với các nhà tư bản kếch xù lĩnh vực Showbiz. Tới năm khoảng 1991, tôi còn nghe lần đầu tiên tài sản của M. Jackson lên tới đỉnh của giới showbiz, xấp xỉ 1 tỷ \$ sau hợp đồng rất lớn với Sony Music.

Thế nhưng, sau chừng 15 năm, vị "Vua" này đã từng lâm vào cảnh nợ nần...

Nhưng như thế vẫn chưa phải khốc liệt. Whitney Houston - ca sĩ lừng danh với Sound Track và vai "gần chính" với Kevin Costner và bài hát "I will always love you", cover lại của Dolly Parton, với sức hát khủng khiếp... đã từng đạt đến đỉnh cao danh vọng, với vô số tiền bạc, hàng trăm triệu và nhiều đêm đón rước trong thảm đỏ trung tâm showbiz ở Hollywood. Và mới đây nhất, một thông tin sửng sốt khoảng giữa năm 2007, người ta tìm thấy cô ca sĩ trẻ đẹp của ca khúc vang dội "My name is not Susan" những năm cuối thập kỷ 80 , ở trong nhà tế bần, sống trong 
cảnh khốn cùng, lay lắt qua ngày cùng với những đồng tiền cứu trợ, mà trong đó không ít người đã từng ngước mắt thầm mơ ước khi nhìn thấy thành công đỉnh cao và tiền bạc rủng rỉnh của cô những năm 90.

Tháng 9 năm ngoái các nhà báo Ân Độ tình cờ phát hiện ra một cô gái bẩn thỉu ăn xin trên đường phố. Họ không thể tin rằng đó chính là Gitanjali Nagpal - Siêu mẫu có tiếng ở Ấn Độ thập niên 1990. Lại một tấm gương nữa của sự khốn cùng đến sau thành công và tiền bạc chói mắt.

Một người khác, tôi (TS Vương Quân Hoàng) trực tiếp biết, là Việt Kiều có mang dòng máu Âu, từ Hồng Kông về Việt Nam làm ăn, và tôi nhớ cỡ những năm 1990, bà có khoảng 6 triệu $\$$, một số tiền cực lớn so với các "đại gia" Việt Nam lúc bấy giờ. Hiện nay, bà cũng sống vất vả với số trợ cấp ít ỏi của con cái, sau kết cục đã đánh mất cái gia sản đã từng cho phép bà ở vị trí giàu có bậc nhất trong xã hội Việt Nam một thời.

Điều gì xảy ra? Tôi (TS Vương Quân Hoàng) chỉ có thể đảm bảo một lý do, inter alia, đó là việc quản lý tài sản cá nhân.

Quản lý tài sản cá nhân vừa có ý nghĩa giữ gìn những giá trị tìm được một cách khó khăn trong cuộc cạnh tranh khốc liệt, vừa tiếp tục lao động để xây đắp nó, và tìm phương tiện đầu tư để nó sinh sôi nảy nở. Ý nghĩa chỉ có thế, không hơn không kém.

Tuy nhiên, việc làm đó không dễ, và các kết cục đã thống kê là bằng chứng rõ nét. Trước tiên, tài sản cá nhân không phải công ty, cho nên chúng thường được đối xử không như cách quản lý của công ty. Nói cách khác, cá nhân quyết và sai lầm có thể làm dốc ngược túi! Điều này khá giống như cá nhân nhỏ đánh chứng khoán là đầu tư một cách không chuyên, vì ít thời gian, ít thông tin, không có trợ giúp, và đối thủ của họ trên thị trường lại là các công ty, chuyên tâm, nhiều thời gian cho việc ấy, đầy ắp thông tin và đầy đủ bộ sậu phân tích, quan sát, quan hệ...

Một cái khó khác nữa là sự tin tưởng. Tài sản cá nhân ít ai đặt niềm tin cho người khác quản lý, cho dù người ấy có gần gũi và tài năng đến mấy. Dịch vụ cho việc đầu tư bảo toàn tài sản này ở Việt Nam hiện cũng rất rất hạn chế. Quá lắm thì "dịch vụ miễn phí" hỏi thăm bạn bè, người quen... và chúng ta đều biết chất lượng của "dịch vụ miễn phí" nó thế nào. There is nothing as free lunch. Sự khốc liệt nằm ở chỗ, các khoản đầu tư sai sẽ dẫn đến thảm họa toàn cục, bất kể trước đó giàu có tới mức nào.

Cuộc càn quét thảm khốc của thị trường chứng khoán và bất động sản ở Việt Nam 2007-2008 và sắp tới đây 2009, sẽ tiếp tục đặt ra câu hỏi sát sườn cho hàng triệu người Việt Nam: Quản lý tài sản cá nhân thế nào? Những mất mát lớn không chỉ là dấu hỏi lơ lửng trên đầu, mà đang là cái móc thít cổ khó thở hàng trăm ngàn người "suýt giàu".

Các mẹ các chị, nửa kia của doanh Nhân, sẽ vô cùng quan tâm tới phần việc đang được giao cho mình, và rất nhiều lúc hơi quá sức.

Quản lý tài sản cá nhân là một môn khoa học, chứ không phải chỉ đơn giản là vấn đề "nho nhỏ" của cuộc sống. Vâng, Personal Finance là một môn khoa học tài chính, hiện đang bắt rất nhiều bà nội trợ phải "kiêm giảng" trong gia đình. 


\section{Tài liệu tham khảo:}

[1] Vương Quân Hoàng. (2007). Văn minh làm giàu \& Nguồn gốc của cải. Nxb Chính trị quốc gia, Hà Nội.

[2] Vương Quân Hoàng, Ngô Phương Chí. (2000). Nguyên lý tài chính toán của thị trường chứng khoán. Nxb Chính trị quốc gia, Hà Nội. 